\title{
Is There A Relationship Between Critical Shoulder Angle and Fatty Degeneration and Number of Damaged Tendons in Rotator Cuff Arthropathy Patients?
}

\author{
Rotator Manşet Artropatili Hastalarda Kritik Omuz Açısı ile Yağlı Dejenerasyon ve Hasarlı Tendon Sayısı Arasında
} İlişki Var Mıdır?

Department of Orthopaedics and Traumatology, Eskisehir Osmangazi University, Faculty of Medicine, Eskisehir, Turkey
Correspondence:

Cuneyd GUNAY

Department of Orthopaedics and Traumatology, Eskisehir Osmangazi University, Faculty of Medicine, Eskisehir, Turkey

e-mail: cungunay@hotmail.com
Cuneyd Gunay, Mustafa Kavak

\section{Abstract}

The aim of this study was to investigate the correlation of critical shoulder angle (CSA) in rotator cuff arthropathy patients with number of damaged rotator cuff tendons and muscle fatty degeneration. Rotator cuff arthropathy patients were included in this study. True antero-posterior radiographs (Grashey view) were used to measure the angle by the first author. The critical shoulder angles were measured on radiographs. The Magnetic resonance images (MRI) of same patients were assessed in terms of number of tendon involvements and fatty degeneration of rotator cuff muscles. There were 28 rotator cuff arthropathy patients comprising 16 females and 12 males. The mean age was $69.92 \pm 8.84$ years. The right shoulder was affected in 20 patients. The left side was affected in 8 patients. The damaged rotator cuff tendons were as follows; supraspinatus tendon was affected in all patients, infraspinatus tendon was affected in 25 patients, teres minor was affected in 14 patients, and subscapularis tendon was affected in 24 patients. The critical shoulder angle was found $37.60^{\circ} \pm 1.66^{\circ} \mathrm{CSA}$ values were found to be higher in patients having fatty degeneration than others having no fatty degeneration, and it was statistically significant $(p<0.001)$. The CSA values were found to be higher in patients with having increased number of damaged tendons and with having fatty degeneration of rotator cuff muscles. The higher CSA means the worse rotator cuff arthropathy patients, therefore care should be taken for planning surgical treatment options.

Keywords: Critical shoulder angle; shoulder; rotator cuff tears; radiography; fatty degeneration

\section{Özet}

$\mathrm{Bu}$ çalışmanın amacı rotator manşet artropatili hastalarda kritik omuz açısının (KOA) hasarlı rotator manşet tendon sayısı ve kasların yağlı dejenerasyonu ile ilișkisini araștırmaktı. Rotator manșet artropatisi hastaları bu çalışmaya dahil edildi. İlk yazar tarafından açıyı ölçmek için gerçek ön-arka radyografiler (Grashey görünümü) kullanıldı. Kritik omuz açıları radyografilerde ölçüldü. Aynı hastaların Manyetik rezonans görüntüleri (MRG), tendon tutulumlarının sayısı ve rotator manşet kaslarının yağlı dejenerasyonu açısından değerlendirildi. 16 kadın ve 12 erkekten olușan 28 rotator manșet artropati hastası vardı. Ortalama yaş $69.92 \pm 8.84$ idi. 20 hastada sağ omuz etkilenmişti. 8 hastada sol taraf etkilenmişti. Hasarlı rotator manşet tendonlar şu şekildeydi; Hastaların tamamında supraspinatus tendonu, 25 hastada infraspinatus tendonu, 14 hastada teres minör ve 24 hastada subskapularis tendonu etkilenmişti. Kritik omuz açısı $37.60^{\circ} \pm 1.66^{\circ}$ olarak bulundu. Yağlı dejenerasyonu olan hastalarda KOA değerleri, yağlı dejenerasyonu olmayanlara göre daha yüksek bulundu ve istatistiksel olarak anlamlıydı $(\mathrm{p}<0,001)$. Hasarlı tendon sayısı fazla olan ve rotator manșet kaslarında yağ dejenerasyonu olan hastalarda KOA değerleri daha yüksek bulundu. Daha yüksek KOA, daha kötü rotator manșet artropati hastaları anlamına gelir, bu nedenle cerrahi tedavi seçeneklerinin planlanması için özen gösterilmelidir.

Anahtar Kelimeler: Kritik omuz açısı; omuz; rotator manşet yırtığı; radyografi; yağlı dejenerasyon 


\section{Introduction}

Rotator cuff tears (RCTs) are a common pathologic finding among patients who have shoulder complaints $(1,2)$. Many factors are related with RCTs, such as smoking, advanced age, and activity level $(3,4)$. Rotator cuff tears also can lead to a characteristic series of degenerative changes including proximal humeral migration, superior wear, and inferior osteophyte formation, which are collectively termed rotator cuff tear arthropathy (5). Assessing the critical shoulder angle (CSA) can be helpful during diagnostic evaluation of patients with shoulder pain and can help predict the exact pathology. The CSA is the angle between the plane of the glenoid and the connecting line to the most lateral border of the acromion on the true antero-posterior (AP) radiograph of the shoulder. The measurement is simple and can be obtained from plain radiographs. First, Moor et al. (6) described the CSA, and reported that smaller CSA was associated with glenohumeral osteoarthritis (OA) and a larger CSA was associated with rotator cuff tear (RCT). Biomechanical studies also support the theory that higher CSA is associated with a greater risk for development of an RCT. Massive RCTs often contain a high degree of muscle atrophy, tendon adhesion, and abnormal fatty infiltration; In this study, we aimed to investigate the correlation of CSA with fatty degeneration of cuff muscles and number of torn cuff tendons.

\section{Materials and Methods}

This study was approved by the University Hospital Institutional Review Board Ethics Committee (Number: E-25403353-050.99171587-02.03.202/17). This study is a retrospective analysis of longitudinally collected data between 2019 and 2021. The inclusion criteria for the patients were as follows; 1) Patients diagnosed as rotator cuff arthropathy disease 2) Patients who have not been treated surgically for rotator cuff disease before admitted to our clinic 3) Patients who have had true shoulder AP radiograph and MRI of the affected shoulder joint. Patients exclusion criteria were as follows; 1) If they had previous humerus, scapula, or clavicle fractures 2) If Grashey shoulder radiographs were not available 3) If radiographs were not suitable for measurement because of unclear visualization of bony landmarks 4) If they had previous rotator cuff surgery 5) Other criteria for exclusion were diagnoses of avascular necrosis and inflammatory arthritis. Grashey (true antero-posterior) views were taken with patients in standing-up position while rotating the affected shoulder 30-40 degrees towards to opposite side. Only radiographs with visible joint space and minimal overlap of the posterior and anterior rim of the glenoid were included into this study. All measurements were performed electronically on a picture archiving and communication system (PACS) workstation in our hospital. The CSA was calculated using the technique described by Moor et. al. (6). It was formed between two lines. First line is formed by connecting the superior and inferior bony margins of the glenoid, and second line is drawn from the inferior bony margin of the glenoid to the most lateral border of the acromion bony edge. All patients underwent standardised antero-posterior radiographs and a standard 3Tesla (T) MRI of the shoulder, using a $3.0 \mathrm{~T}$ Siemens Magnetom Verio MRI (Siemens Medical Solutions, Erlangen, Germany) and 4-channel dedicated shoulder coil, with the arm positioned in neutral rotation by the patient's side. The standard shoulder MRI protocol included oblique coronal, oblique sagittal, and oblique axial images oriented to the axes of the glenohumeral joint. The number of damaged rotator cuff tendons were also assessed on MRI views and noted as how many tendons were affected per one patient. Fatty infiltration was evaluated with the criteria established by Goutallier et al., which classifies infiltration into 4 categories on the basis of the number of fatty streaks within the muscle belly on sagittal and coronal views (7). However, in this study fatty degeneration was assessed on MRI views and noted, only as whether presence or absence of pathology in rotator cuff muscles. The shoulder MRI of the patients were also evaluated according to number of involved torn tendons and fatty infiltration of the rotator cuff muscles as well. 


\section{Statistical Methods}

The statistical analysis were performed using IBM SPSS Statistics version 25. The MannWhitney $U$ test was used for the comparison of variables. The categorical variables were expressed as sample size (n) and percent, continuous variables were expressed as mean and standard deviation. $\mathrm{p}<0.05$ was accepted as statistically significant for this study.

\section{Results}

There were 28 rotator cuff arthropathy patients comprising 16 females (57.1\%), and 12 males (42.9\%). The mean age was 69.92 \pm 8.84 years (range: 54-89). The right shoulder was affected in $20(71.4 \%)$ patients. The left side was affected in 8 (28.6\%) patients. The dominant extremity was involved in $21(75 \%)$ patients. The damaged rotator cuff tendons were as follows; supraspinatus tendon was affected in all patients (28 patients, 100\%), infraspinatus tendon was affected in 25 patients $(25 / 28$, $89.3 \%$ ), teres minor was affected in 14 patients $(14 / 28,50 \%)$, and subscapularis tendon was affected in 24 patients $(24 / 28$, $85.7 \%$ ). The critical shoulder angle was found 37.60 \pm 1.66 degrees (range: 35-40 degrees). Each damaged rotator cuff tendons and their relations with the critical shoulder angle are shown on Table 1. Patients with and without fatty infiltration of rotator cuff muscles and its relations with CSA values are presented on Table 2. CSA values were found to be higher in patients having fatty infiltration than others having no fatty infiltration, and it was statistically significant $(p<0.001)$.

Table 1. The mean critical shoulder angle values of 28 patients, and their relevance with each damaged cuff tendon and with fatty degeneration of damaged tendon muscles.

\begin{tabular}{llllll}
\hline & $\begin{array}{l}\text { Damaged } \\
\text { tendon (n) }\end{array}$ & $\begin{array}{l}\text { Non-demaged } \\
\text { tendon (n) }\end{array}$ & $\begin{array}{l}\text { CSA }\left(^{\circ}\right) \text { for damaged } \\
\text { tendon }\end{array}$ & $\begin{array}{l}\text { CSA }\left({ }^{\circ}\right) \text { for } \\
\text { non-damaged } \\
\text { tendon }\end{array}$ & \\
\hline Supraspinatus & 28 & 0 & $37.60^{\circ} \pm 1.66^{\circ}$ & - & $\mathrm{p}<0.001$ \\
Infraspinatus & 25 & 3 & $37.80^{\circ} \pm 1.63^{\circ}$ & $36.00^{\circ} \pm 1.00^{\circ}$ & $\mathrm{p}=0.090$ \\
Teres minor & 14 & 14 & $38.35^{\circ} \pm 1.15^{\circ}$ & $36.85^{\circ} \pm 1.79^{\circ}$ & $\mathrm{p}=0.021$ \\
\hline Subscapularis & 24 & 4 & $37.87^{\circ} \pm 1.56^{\circ}$ & $36.00^{\circ} \pm 1.41^{\circ}$ & $\mathrm{p}=0.042$ \\
\hline
\end{tabular}

CSA (Critical shoulder angle mean \pm Std. Deviation)

Table 2. The relationship between CSA and fatty degeneration

\begin{tabular}{lll}
\hline & Patient (n) & $\mathbf{C S A}\left({ }^{\circ}\right)$ \\
\hline Fatty infiltration $(+)$ & 22 & $38.13^{\circ} \pm 1.35^{\circ}$ \\
Fatty infiltration (-) & 6 & $35.66^{\circ}+1.21^{\circ}$ \\
\hline \multicolumn{2}{l}{ CSA (Critical shoulder angle mean \pm Std. Deviation) }
\end{tabular}

\section{Discussion}

Moor et al. (6) first described the critical shoulder angle (CSA) for patients, who have high propensity for rotator cuff problems. The benefit of using the CSA is that it combines the lateral extension of the acromion and the inclination of the glenoid fossa into a single quantifiable measurement. Once it was introduced, studies demonstrated its strong relationship with rotator cuff tears (8). In addition, the literature has quantified measurement ranges, suggesting that patients with CSAs from $35^{\circ}$ to $39^{\circ}$ are at the highest risk for rotator cuff disease (6). Gerber et al. showed that CSAs $>38^{\circ}$ substantially increase the ratio of joint shear to joint compression forces (instability ratio) and lead to compensatory supraspinatus tendon overload (9). Moor et al. stated that, the mean CSA was $38.0^{\circ}\left(29.5^{\circ}\right.$ to $\left.43.5^{\circ}\right)$ in the RCT group and $28.1^{\circ}\left(18.6^{\circ}\right.$ to $\left.35.8^{\circ}\right)$ in the OA group. Of patients with a $\mathrm{CSA}>35^{\circ}, 84 \%$ were in the RCT group and of those with a CSA $<30^{\circ}$, 93\% were in the OA group (6). Despite using CSA in rotator cuff disease patients evaluation 
preoperatively, also Garcia et al. (10) reported that increased CSA was significantly correlated with worse postoperative outcomes. The average CSA values correlated with rotator cuff disease vary in the literature from $35^{\circ}$ to $39^{\circ}(6)$. Our results obtained for this study was similar with the literature. CSA measurements on radiography could provide a better guidance for assessing and predicting the severity of damaged rotator cuff muscles compared to MRI, which is expensive and time consuming imaging modality according to radiography. It has been shown that a malrotation in the conventional radiographs exceeding $20^{\circ}$ leads to substantial overlap between the anterior and posterior glenoid rims, decreasing the reproducibility (6). Hence, all CSA measurements in this study was done on true antero-posterior (Grashey views) radiographs.

As mentioned by Chalmers et al. (11), the CSA is not correlated with tear size or tear progression, and does not seem to change with time. Their results suggest that the CSA is unlikely to be related to rotator cuff disease and they have found no change in the CSA at a mean of 6 years, suggesting this is a stable measurement. In contrast to this, it was stated that the CSA also may correlate with tear size (12) and might be larger in patients with degenerative cuff tears than in patients with traumatic tears (13). It was reported in a study that (14), concurrent glenohumeral $\mathrm{OA}$ and full-thickness RCT are associated with greater CSA values compared with patients with glenohumeral OA alone. Our study results are consistent with these reports, as our average CSA was $37.60^{\circ} \pm 1.66^{\circ}$ (range: $35^{\circ}-40^{\circ}$ ). In our study, fatty degeneration of the damaged rotator cuff muscles had more CSA values than having no fatty degeneration and were found to be statistically significant $(p<0.001)$. Scheiderer et al. reported a study, in which they have found higher CSA values associated with increased re-tear risk after isolated supraspinatus tendon repair at short-term follow up. The average CSA was $35.3^{\circ}$ for the intact group and 37.4 for the re-tear group. They showed that, the mean CSA for the retear group was significantly higher than that for the intact group $(p=0.014)(15)$. According to our results, we guess that worse damaged cuff muscles may show more CSA values than less damaged cuff muscles. Rotator cuff arthropaty patients need shoulder arthroplasty in their future life. Assessing the CSA values on true antero-posterior radiographs helps us to imagine the severity of the disease. As nearly all shoulder arthroplasty candidates receive preoperative radiographs, we believe the CSA should be measured and used as an adjunct to help determine the need for MRI preoperatively. On MR images, fatty degeneration of damaged cuff muscles can be seen and the best type of surgery planning also can be made for these patients easily. We believe that the CSA may prove to be a useful tool to help orthopaedic surgeons to determine when it is necessary to order a MRI study to evaluate the rotator cuff before surgery. As with all studies, this current study is not without limitations. First, the retrospective nature of the study may have introduced bias. Second, being lack of multiple observers grading radiographs, and increasing the number of graders may have changed our results. Third, having small number of patients.

\section{Conclusions}

This study results confirm an association between the CSA and RCTs. Assessing the CSA may be helpful during diagnostic evaluation of patients with severe rotator cuff disease and can help predict the magnitude of the pathology especially fatty degeneration of rotator cuff muscles. However, further prospective research with more patients is warranted to highlight the topic in more detail.

Acknowledgement: We would like to thank Prof. Dr. Ertuğrul Çolak for his support at the statistical analysis of this study. 


\section{REFERENCES}

1. Günay C. Spesifik Omuz Muayene Testlerinin Klinik Etkinliğinin Araştırılması. Osmangazi Tip Dergisi. 2020; 42: 670-81.

2. Günay C, Kavak M. Comparison of SLAP Lesions on MRI and Arthroscopy. Osmangazi Tip Dergisi. 2021;43:258-65.

3. Bishop JY, Santiago-Torres JE, Rimmke N, Flanigan DC. Smoking Predisposes to Rotator Cuff Pathology and Shoulder Dysfunction: A Systematic Review. Arthroscopy. 2015;31:1598-605.

4. Lazarides AL, Alentorn-Geli E, Choi JH, Stuart JJ, Lo IK, Garrigues GE, Taylor DC. Rotator cuff tears in young patients: a different disease than rotator cuff tears in elderly patients. $J$ Shoulder Elbow Surg. 2015;24:1834-43.

5. Hamada K, Fukuda H, Mikasa M, Kobayashi Y. Roentgenographic findings in massive rotator cuff tears. A long-term observation. Clin Orthop Relat Res. 1990;92-6.

6. Moor BK, Bouaicha S, Rothenfluh DA, Sukthankar A, Gerber C. Is there an association between the individual anatomy of the scapula and the development of rotator cuff tears or osteoarthritis of the glenohumeral joint?: A radiological study of the critical shoulder angle. Bone Joint J. 2013;95-B:93541.

7. Goutallier D, Postel JM, Bernageau J, Lavau L, Voisin MC. Fatty muscle degeneration in cuff ruptures. Pre- and postoperative evaluation by CT scan. Clin Orthop Relat Res. 1994;304:78-83.

8. Moor BK, Wieser K, Slankamenac K, Gerber C, Bouaicha S. Relationship of individual scapular anatomy and degenerative rotator cuff tears. $J$ Shoulder Elbow Surg. 2014;23:536-41.

9. Gerber C, Snedeker JG, Baumgartner D, Viehöfer AF. Supraspinatus tendon load during abduction is dependent on the size of the critical shoulder angle: A biomechanical analysis. J Orthop Res. 2014;32:952-7.

10. Garcia GH, Liu JN, Degen RM, Johnson CC, Wong AC, Dines DM, Gulotta LV, Dines JS. Erratum to "Higher critical shoulder angle increases the risk of retear after rotator cuff repair" [J Shoulder Elbow Surg 2017;26:241245]. J Shoulder Elbow Surg. 2017;26:732.

11. Chalmers PN, Salazar D, Steger-May K, Chamberlain AM, Yamaguchi K, Keener JD. Does the Critical Shoulder Angle Correlate With Rotator Cuff Tear Progression? Clin Orthop Relat Res. 2017;475:1608-17.

12. Blonna D, Giani A, Bellato E, Mattei L, Caló M, Rossi R, Castoldi F. Predominance of the critical shoulder angle in the pathogenesis of degenerative diseases of the shoulder. $J$ Shoulder Elbow Surg. 2016;25:1328-36.

13. Balke M, Liem D, Greshake O, Hoeher J, Bouillon B, Banerjee M. Differences in acromial morphology of shoulders in patients with degenerative and traumatic supraspinatus tendon tears. Knee Surg Sports Traumatol Arthrosc. 2016;24:2200-5.

14. Mantell MT, Nelson R, Lowe JT, Endrizzi DP, Jawa A. Critical shoulder angle is associated with full-thickness rotator cuff tears in patients with glenohumeral osteoarthritis. J Shoulder Elbow Surg. 2017;26:e376-e381.

15. Scheiderer B, Imhoff FB, Johnson JD, Aglio J, Cote MP, Beitzel K, Imhoff AB, Arciero RA, Mazzocca AD, Morikawa D. Higher Critical Shoulder Angle and Acromion Index Are Associated With Increased Retear Risk After Isolated Supraspinatus Tendon Repair at Short-Term Follow Up. Arthroscopy. 2018;34:2748-54. 